\title{
AZ31 マグネシウム合金における酸水溶液処理方法
}

\author{
小原 美良* ·瀧川順庸 **。東 健司 **
}

Journal of Japan Institute of Light Metals, Vol. 60, No. 3 (2010), pp. 117-123

\section{Acid aqueous solution treatment method in AZ31 magnesium alloy}

\author{
Miyoshi OHARA*, Yorinobu TAKIGAWA** and Kenji HIGASHI**
}

\begin{abstract}
In order to impart metallic luster to AZ31 magnesium alloy, the conditions of surface treatment were optimized, and the formative mechanism of metallic luster on the surface was inferred from the results of surface analysis. The target of this study was the surface of AZ31 magnesium alloy that was polished by emery paper (\#2000). When the optimal acid aqueous solution treatment was applied, more than $60 \%$ of the magnesium in the film was oxidized. In addition, the thickness of the film was about $55 \mathrm{~nm}$. It was confirmed that hydrogen generation was inhibited under the optimized surface treatment conditions. This optimization was performed by examining oxidant addition and the temperature of the acid aqueous solution, and metallic luster was successfully imparted to the alloy. In the optimal acid aqueous solution treatment, it was found that the reaction rate of magnesium oxide formation was faster than that of the dissolution of magnesium from the film composed of magnesium oxide on the surface. For surface treatment conditions in which a dull surface was obtained, it is speculated that the surface became rough due to the generation of hydrogen.
\end{abstract}

(Received July 16, 2009 Accepted December 10, 2009)

Keywords: AZ31 magnesium alloy, surface treatment, acid aqueous solution, gloss, metallic luster

\section{1. 緒言}

マグネシウム合金は，実用構造用金属材料の中で最も軽 く, 高比強度, 高比剛性, 振動吸収性と放熱性および電磁波 シールド性などにおいて優れた特性や機能性を有している。 しかしながら，他の金属と比して耐食性や室温での加工性な ごが劣っていることが実用化を阻む課題であった。最近，そ の表面処理や加工法に関する革新的技術開発により ${ }^{1) ~ 21)}$ ，一 部の電子機器や輸送機器などの部品にマグネシウム合金が使 用され始めてきた。その中でも特に，携帯電話，ノートパソ コン, デジタルカメラなどの軽量化が必要な機器の筐体など の外装部品などに使用される頻度が高くなっている。

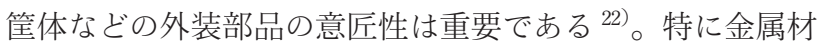
料を使用する場合，本物の素材へのこだわりから金属光沢そ の屯のを可視化した筐体がいくつか製造されている。ステン レス材料やアルミニウム材料を筐体に用いる場合，金属光沢 を具現化する手段として, 電解研磨法や化学研磨法は使用さ

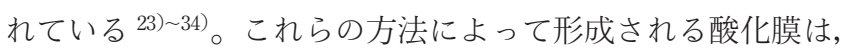
条件や合金成分によって膜厚は異なるが，3７0 nm と非常に 薄い 26),28)。また合金成分のみの安定した酸化膜が形成される ため，耐食性は向上する ${ }^{25) 。 ~}$

外装部品の意匠性として, 素材としての金属材料そのもの の可視化である金属光沢の具現化はマグネシウム合金部品に あ求められている。しかしながら，マグネシウム合金の難点 である耐食性の低さを改善する従来の表面処理法では $\left.{ }^{6)} 21\right)$,
金属光沢の具現化は不可能であり, 他の素材, 例えば樹脂材 料との違いを識別できる意匠性を有していなかった。金属光 沢を具現化し, 耐食性を向上させるためには, 電解研磨法や 化学研磨法で形成される膜のような, 安定した薄い酸化膜の 形成が必要である。マグネシウム合金の電解研磨法や化学研 磨法に関する情報は, 研究室レベルでの報告はあるが 24), 未 だ工業的には使用されていないのが実状である。そこで, 我々は，マグネシウム合金の金属光沢を具現化する方法とし て, 化学研磨法を基にした工業的に利用可能な表面処理方法 である酸水溶液処理方法を開発した ${ }^{35) ~ 39) 。 ~}$

本研究では, 金属光沢を具現化するための酸水溶液表面処 理条件の最適化を検討するとともに, 形成した膜の表面構造 を明らかにすることを目的とした。金属光沢の目標はエメ リー紙＃2000 で研磨した AZ31 マグネシウム合金表面とした。 また, 化学研磨の溶解反応機構で発生する水素が金属光沢を 阻害するという知見から ${ }^{23)}$, 酸化剂添加之表面処理温度の最 適化による水素発生の抑制とその金属光沢に及ぼす効果につ いて検討した。これらの検討結果から，表面処理条件および 表面構造と金属光沢の関係に関して考察した。

\section{2. 実験方法}

試料に, 長さ幅共に $50 \mathrm{~mm}$ に切断した板厚 $0.8 \mathrm{~mm}$ の AZ31 マグネシゥム合金圧延材（以下 AZ31）を使用した。AZ31の 化学組成を Table 1 に示す。試料の表面を, 標準化するため にエメリー紙\#2000で研磨した。その後, 試料を, アセトン

*(梀カサタニ カサタ二研究所（～５32-0036 大阪府大阪市淀川区三津屋中 2-15-21)。 Kasatani Research Institute, Kasatani Corp. (2-15-21, Mitsuyanaka, Yodogawa-ku, Osaka 532-0036).

***阪府立大学大学院工学研究科物質・化学系専攻マテリアル工学分野 (堺市)。Department of Materials Science, Graduate School of Engineering, Osaka Prefecture University (Sakai-shi, Osaka). 
Table 1 Chemical composition of magnesium alloy (mass \%)

\begin{tabular}{c|c|c|c|c|c|c|c}
\hline \hline $\mathrm{Al}$ & $\mathrm{Zn}$ & $\mathrm{Mn}$ & $\mathrm{Si}$ & $\mathrm{Fe}$ & $\mathrm{Cu}$ & $\mathrm{Ni}$ & $\mathrm{Mg}$ \\
\hline 3.15 & 1.06 & 0.38 & 0.02 & 0.002 & 0.001 & 0.0006 & bal. \\
\hline
\end{tabular}

により超音波洗浄し，以下の条件で表面処理を施した。表面 処理液に硝酸, 塩酸, 硫酸を使用し, 各々 $1 \mathrm{~mol} \mathrm{dm}^{-3}$ 以下の 水溶液に調整した。表面処理温度は 278 313K の範囲であ る。表面処理時間は $30 \mathrm{~s}$ である。試料浸漬時には，超音波周 波数 $28 \mathrm{kHz}$ を付加した。

金属光沢は鏡面光沢度として定量化した。Fig. 1 に光沢計 概念図を示す 37 )。鏡面光沢度の測定は市販の光沢計（日本 電色工業濑製 VG2000）を使用した。JIS 規格において鏡面光 沢度とは，屈折率 $n=1.567$ の黒色ガラス表面を基準として鏡 面反射光の強さの度合を測定し，その度合を数值で表したも のと定義している ${ }^{40)}$ 。例えば，入射角 60 度における基準ガ ラス表面の鏡面反射率は 0.1001 となり，この值が鏡面光沢度 Gs $\left(60^{\circ}\right)=100 \%$ である。

本研究では, 測定時の入射角, 反射角 $\theta$ は共に 60 度とし た。測定位置は試料の中心部とした。研磨方向に対して平行 方向拉よび垂直方向をそれぞれ 2 回ずつ測定し，平均值を鏡 面光沢度 $G s\left(60^{\circ}\right)$ とした。さらに，式（2-1）の上うに，目 標鏡面光沢度と表面処理した試料の鏡面光沢度の比によって 規格化鏡面光沢度 $G s_{N}$ を算出し，これをもって金属光沢を評 価した。目標とする金属光沢は，エメリー紙 \#2000 で研磨 後, アセトン洗浄した試料の鏡面光沢度とした。したがって, 本研究での金属光沢の目標值は 1 となり, この金属光沢を標 準とした。

Normalized gloss, $G s_{N}=\frac{G s\left(60^{\circ}\right): \text { Surface treatment }}{G s\left(60^{\circ}\right): \text { Emery paper \#2000 }}$

\section{3. 実験結果と考察}

\section{1 表面処理液成分と表面処理条件の最適化}

規格化鏡面光沢度 (以下 $G s_{N}$ ) に及ぼす表面処理液成分之 その濃度の影響を Fig. 2 に示す。横軸は硝酸，塩酸，硫酸の 各酸の濃度 $C$ を，綐軸は $G s_{N}$ を示す。 $1 \mathrm{~mol} \mathrm{dm}^{-3}$ 以下の硝酸

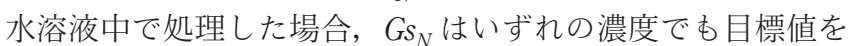
達成し, かつその最大值は濃度が $0.3 \sim 0.5 \mathrm{~mol} \mathrm{dm}^{-3}$ 付近で得 られた。また， $0.4 \mathrm{~mol} \mathrm{dm}^{-3}$ 以下の塩酸水溶液打よび $0.2 \mathrm{~mol}$ $\mathrm{dm}^{-3}$ 以下の硫酸水溶液中で処理した場合, $G s_{N}$ は目標值より も低い值を示し，かつ両液ともその濃度が高くなるほど低下 した。

$G s_{N}$ 之硝酸水溶液濃度 $C$ の関係の表面処理温度依存性を Fig. 3 に示す。試験温度は，278，298，313K の 3 種類とし た。 $278 \mathrm{~K}$ の場合, いずれの濃度でも目標値以上の $G s_{N}$ を得 ることができた。 $298 \mathrm{~K}$ の場合, 約 $0.5 \mathrm{~mol} \mathrm{dm}^{-3}$ 以下の濃度で あれば目標値以上の $G s_{N}$ を得ることができたが，この濃度以 上では $G s_{N}$ は目標値以下となった。この温度では, $G s_{N}$ のば らつきは大きくなったが，その原因は表面全体に発生した光

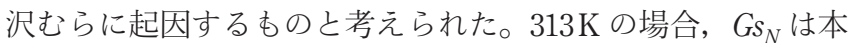
試験範囲内のいずれの濃度でも目標值以下であった。

$G s_{N}$ に及ぼす有機酸添加の効果を有機酸の種類や濃度を変

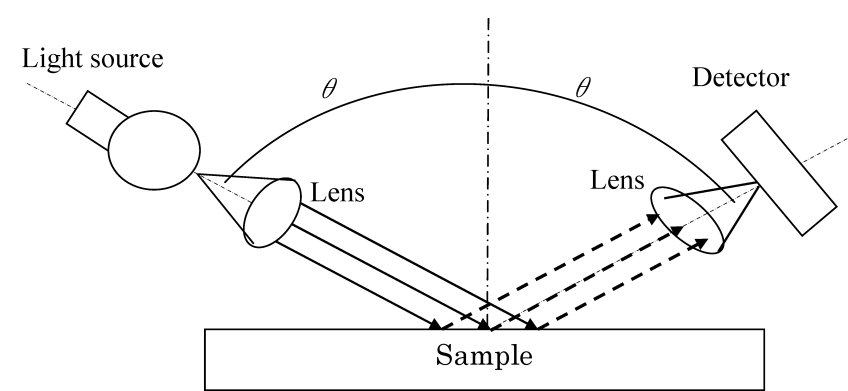

Fig. 1 Conceptual diagram of gloss meter ${ }^{37)}$.

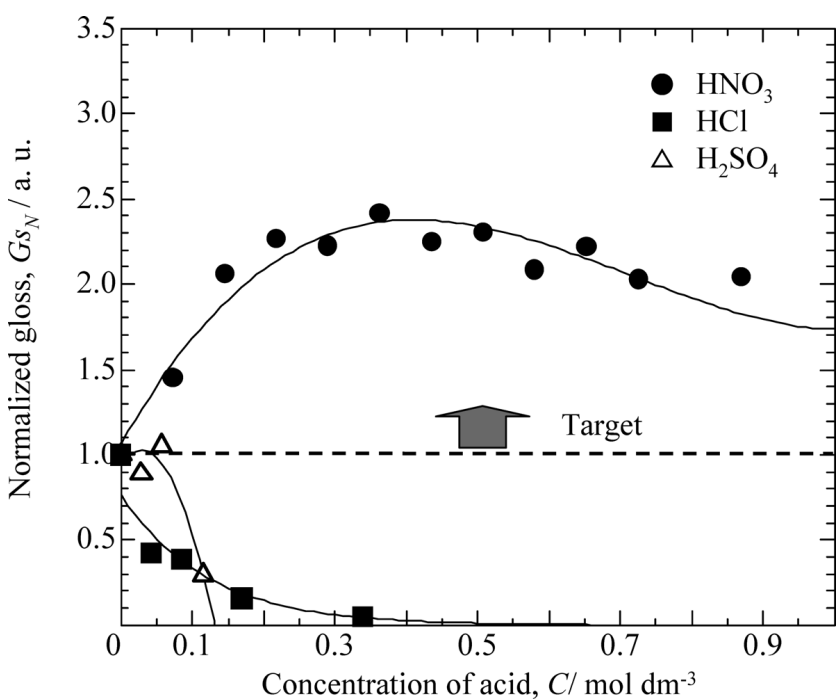

Fig. 2 Effects of acids used in surface treatment at various concentrations, $C$, on normalized gloss, $G s_{N}$.

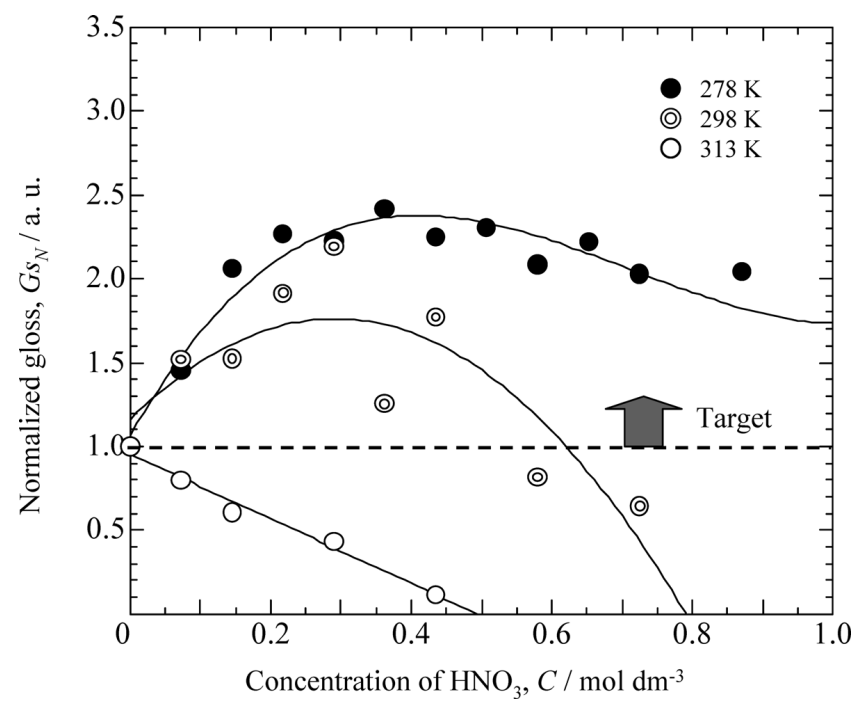

Fig. 3 Effect of concentration, $C$, and temperature of nitric acid aqueous solution on normalized gloss, $G s_{N}$.

えて検討した。代表的な結果を Fig. 4 に示す。 $0.36 \mathrm{~mol} \mathrm{dm}^{-3}$ 硝酸水溶液に比べ, 有機酸を $0.01 \mathrm{~mol} \mathrm{dm}^{-3}$ 添加した処理液の 方が $G s_{N}$ は向上した。

以上の結果から，超音波周波数 $28 \mathrm{kHz}$ 付加状態で $30 \mathrm{~s}$ 間 浸漬する表面処理条件において, 最適な表面処理液は 0.3 0.5 mol dm ${ }^{-3}$ 硝酸に $0.01 \mathrm{~mol} \mathrm{dm}^{-3}$ 有機酸を添加した水溶 液であり，最適な温度は $278 \mathrm{~K}$ であることを明らかにした。 


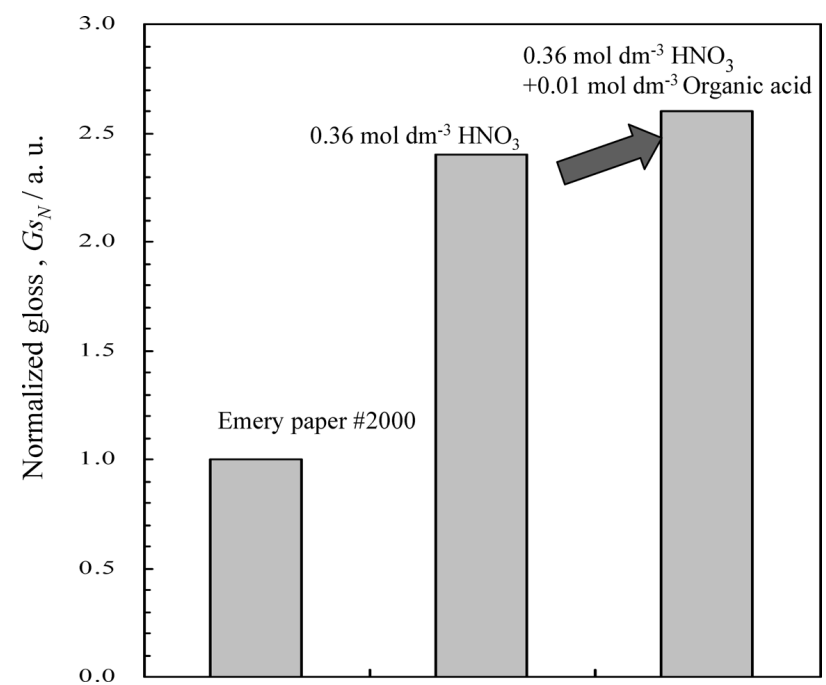

Fig. 4 Effect of addition of organic acid on normalized gloss, $G s_{N}$.

以下，この条件を最適酸水溶液処理とした。

\section{2 表面構造の確認}

（a）エメリー紙＃2000で研磨した表面，および（b）最適 酸水溶液処理後の表面を対象として, 表面近傍の構成元素に ついて高周波グロー放電発光分光分析（以下 GD-OES）を用 いて深さ方向に分析した結果を Fig. 5 に示す。横軸は表面か らの深さ $d$, 縦軸は濃度 $C$ を示すが, これらは分析時のス パッ夕時間と強度比から換算した值を用いている ${ }^{41)}$ 。膜厚は 酸素の最大值が半分の值（半值幅）になる深さとした。この 膜厚決定方法は, 通常使用されている方法である 26),28)。エメ リー紙 \#2000 で研磨した表面の酸化膜厚は $10 \mathrm{~nm}$ であり, 最 適酸水溶液処理を適用した表面の酸化膜厚は $55 \mathrm{~nm}$ と, 厚く なっていた。

次に, 酸素量とマグネシウム量に注目して表面皮膜中のマ グネシウムの酸化量を解析した。Fig. 5 の分析結果から, エ メリー紙＃2000で研磨した表面の皮膜中の酸素量に比べて, 最適酸水溶液処理を適用した表面の皮膜中の酸素量が多く, 特に深さ $10 \mathrm{~nm}$ 付近から約 $30 \mathrm{~nm}$ 範囲の酸素量が一定值を示 すことが理解できる。さらに, 最適酸水溶液処理を適用した 表面について, $\mathrm{O}_{1 \mathrm{~s}}$ と $\mathrm{Mg}_{2 \mathrm{p}}$ の深さ方向の $\mathrm{X}$ 線光電子分光分析 を行った過去の結果 ${ }^{35), 36)}$, 酸化マグネシウムのピークが検出 した。しかしながら，酸化マグネシウム量は定量的に解析で きなかった。そこで, GD-OESによって検出した酸素量とマ グネシウム量を用い, 以下のように皮膜中のマグネシウム酸 化量を算出した。

まず，エメリー紙＃2000 で研磨した試料と最適表面処理し た試料における, Fig. 5 で決定した皮膜中の酸素量とマグネ シウム量の平均值を算出し, その值を分析值とした。また, Fig. 5 の最適表面処理した試料の酸素量とマグネシウム量が 一定量である領域（約 $30 \mathrm{~nm}$ 範囲）についても，同様に酸素 分析值とマグネシウム分析值を算出した。次に, 酸素分析值 とマグネシウム分析值の比 $(\mathrm{O} / \mathrm{Mg})$ を算出した。酸化マグネ シウム生成反応における酸素とマグネシウムの重量比は, 0.67 である。すなわち, 皮膜中のマグネシウムがすべて酸化マグ ネシウムになるならば $\mathrm{O} / \mathrm{Mg}$ は 0.67 になる。この值を $\mathrm{O} / \mathrm{Mg}$ 理論值とした。皮膜中のマグネシウム酸化量として, $\mathrm{O} / \mathrm{Mg}$

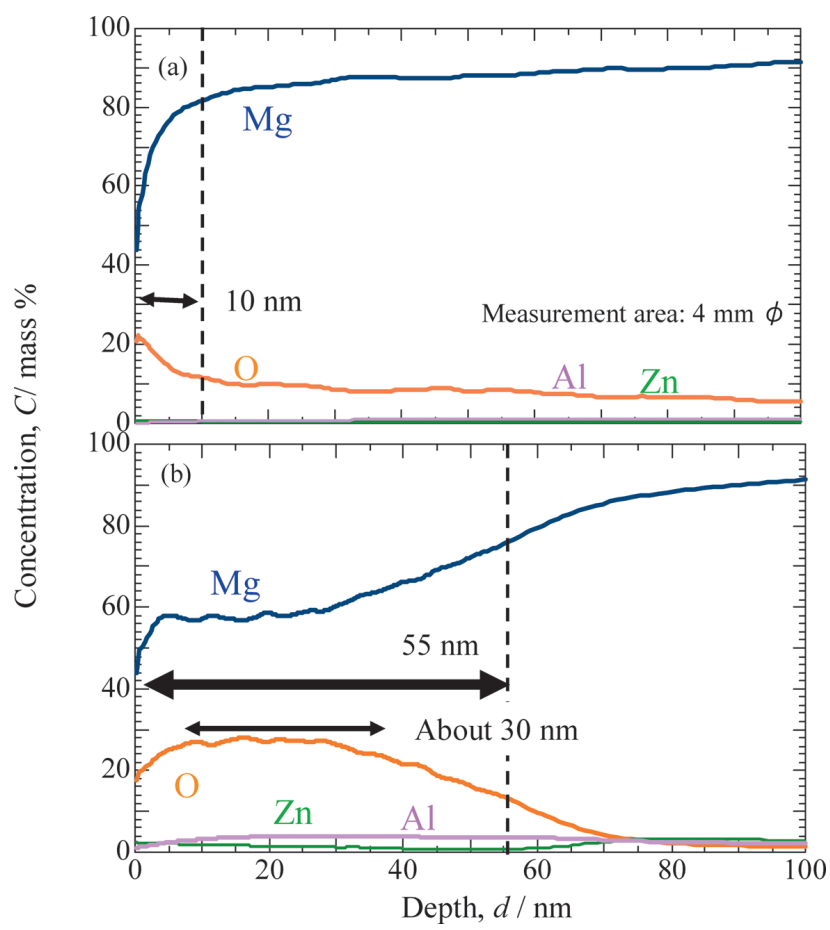

Fig. 5 Depth profiles of constituent elements of the specimen using Glow discharge optical emission spectrometer: (a) surface polished by emery paper \#2000 and (b) surface after optimal acid aqueous solution treatment.

Table 2 Amount of oxidized magnesium in film calculated from results of surface analysis

\begin{tabular}{|c|c|c|c|c|}
\hline & \multicolumn{2}{|c|}{ Analysis (mass \%) } & \multirow{2}{*}{$\mathrm{O} / \mathrm{Mg}$} & \multirow{2}{*}{$\begin{array}{c}\mathrm{MgO} \\
\text { in Film } \\
(\%)\end{array}$} \\
\hline & $\mathrm{Mg}$ & $\mathrm{O}$ & & \\
\hline $\begin{array}{l}\text { Emery paper \#2000 } \\
\text { (Average) }\end{array}$ & 70 & 16 & 0.23 & 34 \\
\hline $\begin{array}{l}\text { Optimal acid aqueous } \\
\text { solution treatment } \\
\text { (Average) }\end{array}$ & 61 & 24 & 0.39 & 58 \\
\hline 30-nm oxide film & 58 & 27 & 0.47 & 70 \\
\hline Theoretical value & & & 0.67 & \\
\hline
\end{tabular}

理論值に対する試料の $\mathrm{O} / \mathrm{Mg}$ 值の百分率を算出した。この計 算は, 検出した酸素がすべて酸化マグネシウムのものと仮定 して行った。

皮膜中のマグネシウム酸化量の算出結果を Table 2 に示 す。エメリー紙 \#2000で研磨した表面の皮膜中のマグネシウ ムは $34 \%$ が酸化していた。一方, 最適酸水溶液処理を適用 した表面の皮膜中のマグネシウムは平均 $58 \%$ が酸化し, マ グネシウムの酸化がかなり促進されていた。Fig. 5 (b) にお いて $40 \mathrm{~nm}$ 付近から $70 \mathrm{~nm}$ にかけて酸素量は減少し, マグネ シウム量は増加した。GD-OESの場合, このような遷移曲線 は皮膜厚さのばらつきによるあのであると報告されている ${ }^{41)}$ 。 つまり, Fig. 5 (b) の $40 \mathrm{~nm}$ 付近より深い部分のマグネシウ ムは母材の金属マグネシウムであると推測できる。それゆえ, 


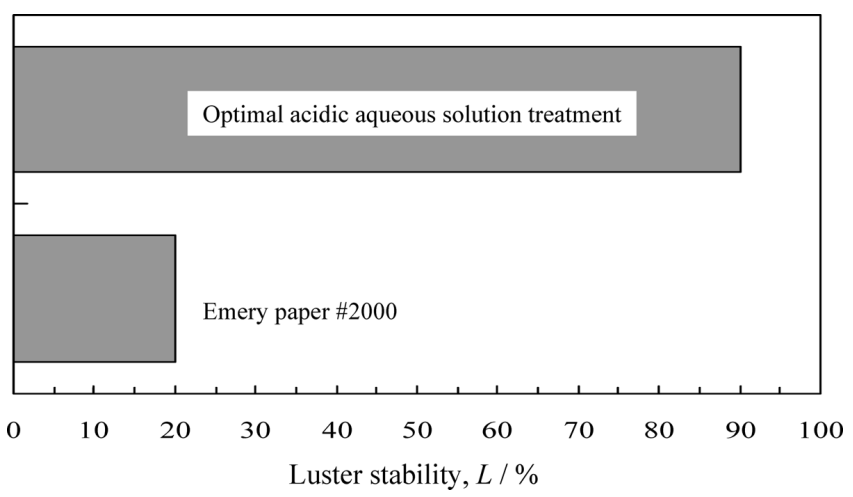

Fig. 6 Luster stability, $L$, of specimen with and without optimal acid aqueous solution treatment. Luster stability, $L$, was quantified by ratio of specular gloss, Gs $\left(60^{\circ}\right)$, before and after environment test. Temperature, humidity and time of environment test were in $333 \mathrm{~K}, 95 \%$ and $604.8 \mathrm{ks}$, respectively.

酸素の半值幅によって決定した膜厚 $55 \mathrm{~nm}$ には皮膜厚さのば らつきの領域が含まれ，金属マグネシウムが存在すると推測 できる。またマグネシウム量と酸素量が一定量で安定した皮 膜構造が形成されていると予想される領域（約 $30 \mathrm{~nm}$ 範囲） では, Table 2 に示すように，ママグネシウムは $70 \%$ が酸化し ていた。この約 $30 \mathrm{~nm}$ 範囲の領域は，上述した皮膜厚さのば らつき領域でなく皮膜のみが存在する領域であると推測でき るため，皮膜中には酸化していないマグネシウム，すなわち 金属状態のマグネシゥムが存在すると推測した。

最適酸水溶液処理後の金属光沢の経時変化を確認するため に環境試験前後の光沢安定性を検討した。Fig. 6 は, 最適酸 水溶液処理の有無による光沢安定性 $L$ を調べた結果である。 光沢安定性 $L$ は, 環境試験前後の鏡面光沢度 $G s\left(60^{\circ}\right)$ の比 で定量化した。環境試験条件は, 温度 $333 \mathrm{~K}$, 湿度 $95 \%$ ，時 間 $604.8 \mathrm{ks}$ とした。エメリー紙 \#2000で研磨した表面の光沢 安定性 $L$ は約 $20 \%$ であったが, 最適酸水溶液処理により約 $90 \%$ の光沢安定性 $L$ を得ることができた。これにより最適酸 水溶液処理の有用性が確認できた。

最適酸水溶液処理を適用した試料の（a）環境試験前之 （b）環境試験後の表面を, 微小角入射 X 線回折に上り分析 した結果を Fig. 7 に示す。微小角入射 X線回折測定は, SPring-8 のビームライン BL19B2 を使用した。入射角は約 0.1 度とした。環境試験前後でそのプロファイルに変化が見られ ないことから，環境試験による表面構造に変化がないことを 示している。Fig. 8 は, AZ31 のエメリー紙 \#2000で研磨し た表面に打ける（a）環境試験前と（b）環境試験後の表面を 微小角入射 X 線回折により分析した結果である。酸化マグネ シウムは，環境試験前では検出されるが，環境試験後では検 出されず，水酸化マグネシウムが検出された。この結果から， エメリー紙 \#2000 で研磨した試料の場合, 表面のマグネシウ ムは酸化しているものの環境試験に充分耐える程度ではな かったことが明らかとなった。

\section{3 酸化剂添加亡表面処理温度の最適化による水素発生 の抑制とその金属光沢に及ぼす効果}

最適表面処理では，3.2 で示したように表面に酸化マグネ シウムが形成した。この最適表面処理では酸化剂である硝酸 水溶液を使用しているため, 次式のような反応が起こったと

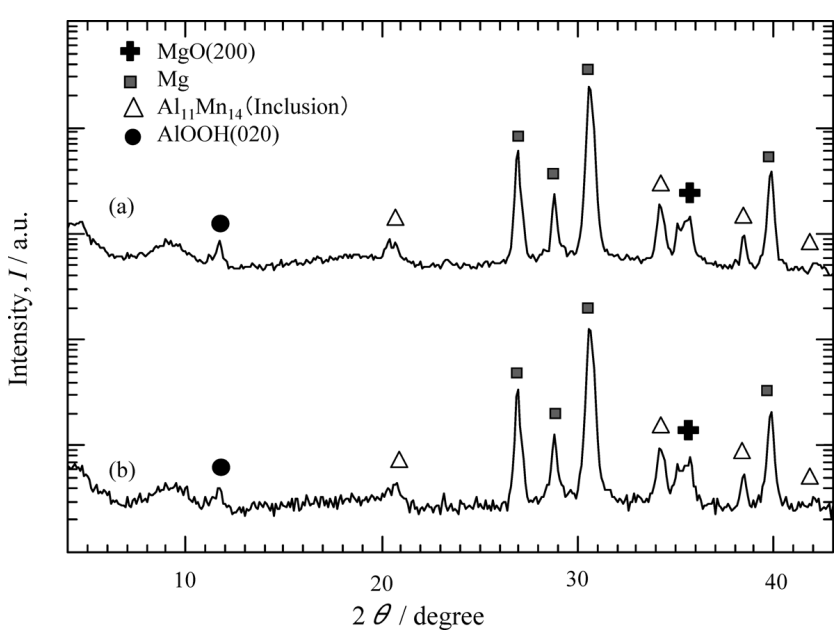

Fig. 7 Grazing incidence X-ray diffraction profiles of AZ31 magnesium alloy with the optimal surface treatment. (a) before and (b) after environment test.

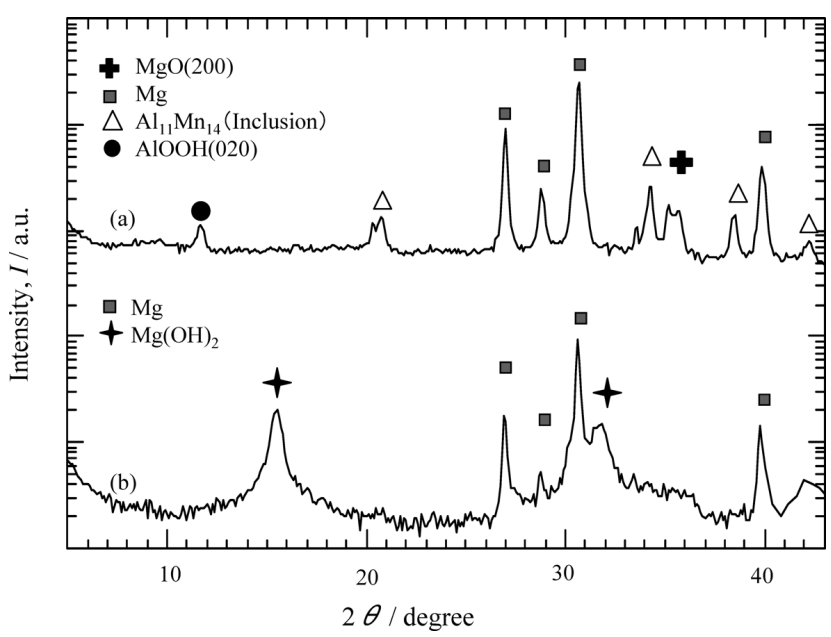

Fig. 8 Grazing incidence X-ray diffraction profiles of AZ31 magnesium alloy polished by emery paper \#2000. (a) before and (b) after environment test.

推測できる。

$$
\begin{aligned}
& 2 \mathrm{HNO}_{3}+6 \mathrm{e}^{-} \rightarrow 2 \mathrm{NO}+\mathrm{H}_{2} \mathrm{O}+3 \mathrm{O}^{2-} \\
& \mathrm{Mg}+\mathrm{O}^{2-} \rightarrow \mathrm{MgO}+2 \mathrm{e}^{-} \\
& \mathrm{MgO}+2 \mathrm{HNO}_{3} \rightarrow \mathrm{Mg}\left(\mathrm{NO}_{3}\right)_{2}+\mathrm{H}_{2} \mathrm{O}
\end{aligned}
$$

酸化物イオン $\left(\mathrm{O}^{2-}\right)$ は金属のアノード酸化における酸化機 構と同様に ${ }^{42)}$, 酸化皮膜と溶液の界面で生成し固体イオンと して酸化皮膜中を移動すると推測した。これらをまとめた式 が式（3-4）である。生成した硝酸マグネシウムは式（3-5）で 示すように硝酸水溶液中に溶解する。

$$
\begin{aligned}
& 3 \mathrm{Mg}+8 \mathrm{HNO}_{3} \rightarrow 3 \mathrm{Mg}\left(\mathrm{NO}_{3}\right)_{2}+2 \mathrm{NO}+4 \mathrm{H}_{2} \mathrm{O} \\
& \mathrm{Mg}\left(\mathrm{NO}_{3}\right)_{2} \rightarrow \mathrm{Mg}^{2+}+2 \mathrm{NO}_{3}{ }^{-}
\end{aligned}
$$

式（3-4）に示した溶解反応は水素を発生しない反応である。 理論的には硝酸水溶液中におけるマグネシウム溶解反応は, 次式に示す水素発生反応も存在する。 


$$
\mathrm{Mg}+2 \mathrm{HNO}_{3} \rightarrow \mathrm{Mg}\left(\mathrm{NO}_{3}\right)_{2}+\mathrm{H}_{2}
$$

酸化剂を含まない塩酸水溶液や硫酸水溶液を用いた表面処理 におけるマグネシウム溶解反応は，式（3-6）で示した水素発 生反応之同様な反応のみが起こる。以上のように酸水溶液を 用いた表面処理におけるマグネシウム溶解反応は，水素発生 反応と水素を発生しない反応が存在する。この水素発生は, 金属光沢を得るための研磨機構に有害な作用を及ぼすことが 知られている ${ }^{23)}$ 。それゆえ，水素検知器を用いて簡易的に表 面処理中の水素発生量を測定し，金属光沢と水素発生量の関 係を検討した。

3 種類の表面処理条件における金属光沢之水素発生量の関 係の模式困を Fig. 9 に示す。塩酸水溶液で処理したとき，水 素検知器の測定限界 $(10,000 \mathrm{ppm})$ を超え，水素が最も多く 発生した。硝酸水溶液を用いて処理したときの水素発生量は $10,000 \mathrm{ppm}$ 以下であった。そして，その硝酸水溶液の温度が より低い方（温度 $278 \mathrm{~K} ）$ の水素発生量は $1,000 \mathrm{ppm}$ 以下と少 なくなった。これに呼応して，水素発生が最も少なかった硝 酸水溶液処理（温度 $278 \mathrm{~K}$ ）された試料の金属光沢が最屯高 く, 逆に水素発生が顕著であった塩酸水溶液処理された試料 の金属光沢が最む低い結果になった。この結果は，表面処理 液や表面処理温度の最適化によって水素発生が抑制され，金 属光沢が向上することを明らかにした。

処理温度 $278 \mathrm{~K}$ と $313 \mathrm{~K}$ の硝酸水溶液処理における溶解速 度と $G s_{N}$ の関係を過去に検討した ${ }^{39)}$ 。その結果, 溶解速度に かかわらず処理温度 $278 \mathrm{~K} の G s_{N}$ は高い值を示した。また， 溶解速度が遅い条件であっても処理温度 $313 \mathrm{~K}$ の $s_{N}$ は低い 值を示した。さらに, 硝酸水溶液と塩酸水溶液を用いて溶解 速度と $G s_{N}$ の関係を検討した結果，溶解速度にかかわらず硝 酸水溶液の $G s_{N}$ は高い值を示した ${ }^{39)}$ 。以上の結果は, 金属光 沢を得るための水素発生の抑制が，単に溶解速度を制御する だけではできないことを示唆した。

塩酸水溶液処理の水素発生量が多い理由は, 式（3-6）と 同様な水素発生反応のみが起こるためであると推測できる。 溶解速度を制御する以外で水素発生を抑制するためには，式 （3-4）に示したような水素を発生しない反応を起こすことが 挙げられる。水素を発生しない反応が起こることにより水素 発生が抑制できるとすれば，塩酸水溶液に硝酸のような酸化 剂を添加することで金属光沢が得られると推測できる。そこ で, 塩酸水溶液に酸化剂である硝酸アンモニウムを添加して, 金属光沢の向上に及ぼす酸化剂の効果を検討した。Gs いする酸化剂の添加効果を Fig. 10 に示す。硝酸アンモニウ 厶 $0.6 \mathrm{~mol} \mathrm{dm} \mathrm{m}^{-3}$ を添加した塩酸水溶液を用い表面処理温度 $278 \mathrm{~K}$ で処理した結果， $G s_{N}$ は高い值を示した。この結果か ら，酸化剤の添加は金属光沢の向上に効果的あることを明確 化した。また酸化剤を添加した塩酸水溶液処理では，水素を 発生しない反応が起こり水素発生が抑制されたと推測した。

\section{4 金属光沢と表面構造との関係に関するまとめ}

金属光沢と表面構造との関係に関してこれまでに得られた 成果をまとめた概念図を Fig. 11 に示す。ここでは，金属光 沢が得られる条件と金属光沢が得られない条件の概念図を示 している。また，金属光沢が得られない条件には 2 種類の ケースが存在する。

金属光沢が得られる条件では，表面構造は表面皮膜中のマ
Metallic luster

Hydrogen gas yield

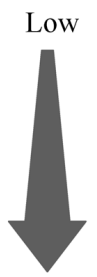

High

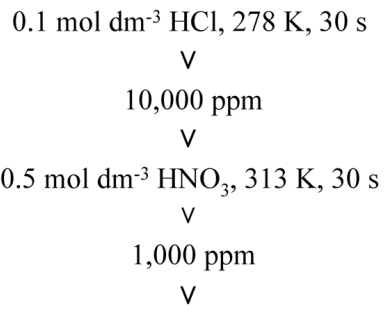

$0.5 \mathrm{~mol} \mathrm{dm}^{-3} \mathrm{HNO}_{3}, 278 \mathrm{~K}, 30 \mathrm{~s}$

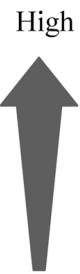

Low
Fig. 9 Relationship between metallic luster and amount of hydrogen generation in surface treatment conditions.

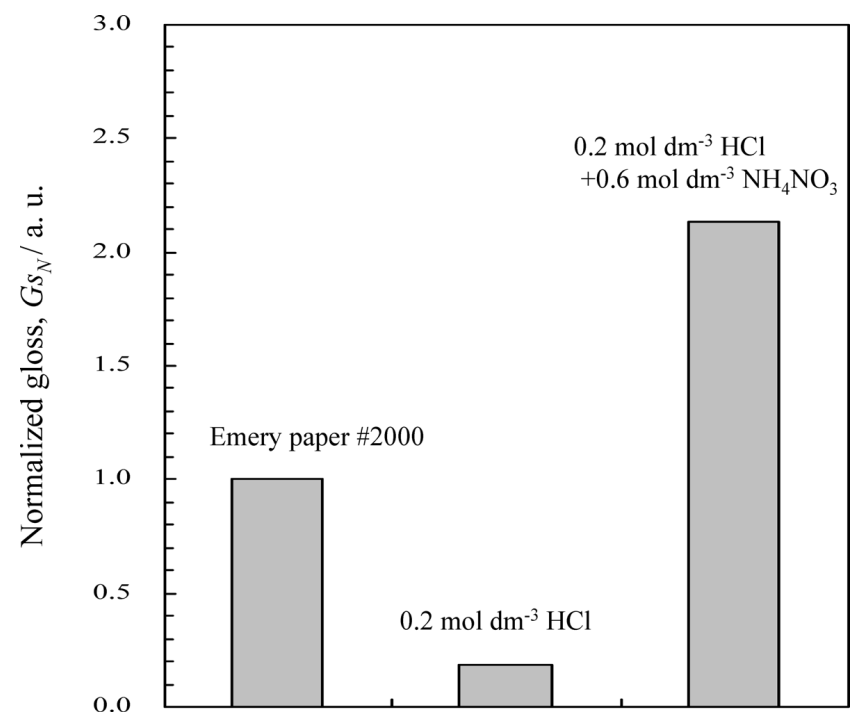

Fig. 10 Effect of oxidant addition on normalized gloss, $G s_{N}$.

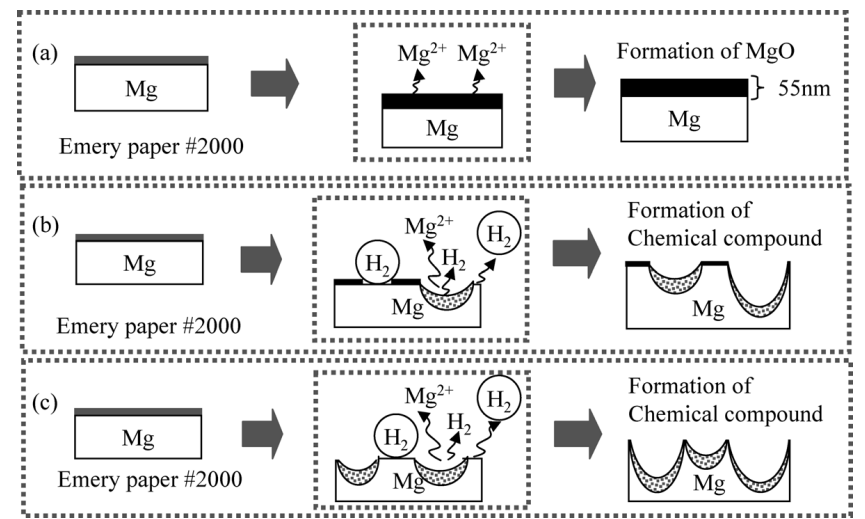

Fig. 11 Conceptual diagram summarizing findings on relationship between metallic luster and surface structure.

(a) Surface treatment with oxidant obtaining metallic luster.

(b) Surface treatment with oxidant obtaining dull surface.

(c) Surface treatment without oxidant obtaining dull surface.

グネシゥムの約 $60 \%$ 以上が酸化されている膜質から構成さ れ, かつその膜厚が $55 \mathrm{~nm}$ 程度であった。このような表面構 造が形成されるためには, 酸化マグネシウムの形成反応速度 が酸化マグネシウムからのマグネシウムの溶解速度よりも速 いことが必要である。また, 酸化マグネシウムが生成するた めには, まず酸化剤が必ず処理液中に含まれることが必須で 
ある。一方，酸化マグネシウムの形成速度と酸化マグネシウ ムからのマグネシウムの溶解速度が一致する条件では, 浸漬 初期から酸化マグネシウムは形成されない。この一致する条 件は表面処理液の成分と処理温度によって決定される。ある 特定成分の表面処理液ではこの条件は処理温度により一義的 に決まるものと推測される。Fig. 3 で示したように，酸化剤 が表面処理液中に存在する場合は，処理温度が低いほど金属 光沢が向上した。処理温度が低くなれば，酸化マグネシウム の形成速度が酸化マグネシウムからのマグネシウムの溶解速 度より屯速くなるということが推測される。この推測が正し いとすれば，表面処理液中に酸化剂が存在し，かつ処理温度 が低温であるような条件下では形成される酸化膜は結果的に 厚くなると考えられる。Fig. 5 の結果は, 酸化刘の存在する 低温化での表面処理液で処理した試料の表面皮膜の厚みが $55 \mathrm{~nm}$ 程度であり，エメリ一紙＃2000 で研磨した表面皮膜の 厚み $(10 \mathrm{~nm}$ 程度) より厚くなることを示している。この推 察を概念的にした図が Fig. 11 (a) に対応する。

金属光沢が得られない条件には, 表面処理液の成分に酸化 剂を含む条件と含まない条件がある。Fig. 3 および Fig. 9 で示 したように，酸化剂が表面処理液中に存在する場合，表面処 理温度が高いほど金属光沢は低下し, 水素発生量は増加し た。表面処理液の成分に酸化剂が含む条件の場合, 前述した ように表面処理温度は, 表面の酸化マグネシウムの厚みを決 定すると推測できる。ここで表面処理温度が高い条件とは, 前節で考察した酸化マグネシウムの形成速度と酸化マグネシ ウムからの溶解反応が一致する表面処理温度近傍であり，か つ酸化マグネシウムの形成反応が溶解反応上りも速い条件を 示す。この条件では, 表面に非常に薄い酸化膜が形成する。 このように非常に薄い酸化膜を形成する条件の場合, 酸化膜 が均一に形成するとは考えにくく, 酸化膜が形成していない 部分も存在すると推測できる。酸化膜が形成していない部分 が存在するとすれば，この部分では式（3-6）に示した水素発 生反応が起こる。水素発生反応が起こる場所では, 水素ガス が吸着してマグネシウムの溶解を阻害する部分と吸着せずに マグネシウムの溶解が進む部分が存在すると推測できる。こ の溶解の差によって表面粗さが大きくなると推測した。以上 の推測を概念的に示した図が Fig. 11 (b) に対応する。上述し たように，水素ガスの吸着が溶解の差異を起こすという議論 は充分されていないが，化学研磨に拈いて，水素発生反応に より形成した水素ガスの気泡が表面処理液と金属表面との間 に介在し，表面の均一溶解を阻害して金属光沢が得られな かったという推測が報告されている ${ }^{25)}$ 。

他方, 酸化剂が表面処理液の成分に含まれていない場合の 概念図を Fig. 11 (c) に示す。この条件では, Fig. 2 で示した ように金属光沢は初期值より低下した。また Fig. 9 で示した ように水素発生量が多い。表面処理液成分に酸化剂が含まな いため, 酸化マグネシウムが生成されないので, 当然この条 件での反応は, 式（3-6） と同様に水素発生反応のみが起こ る。したがって, Fig. 11（b）で説明したように水素ガスの吸 着による不均一溶解が起こるため表面粗さが大きくなり, 結 果，金属光沢が得られなかったものと推測できる。これらの 表面形態の定量化について今後詳細な検討が必要である。

金属光沢が得られない条件の試料を深さ方向に GD-OESを 用いて分析した結果, 表面にマグネシウム, 酸素, アルミニ
ウム，亜鉛が検出された。アルミニウム濃度と亜鉛濃度は， 金属光沢が得られた条件の表面よりも高い值を示した。それ ゆえ，アルミニウムむしくは亜鉛を含む何らかの化合物が表 面層に形成されていると推測できる。しかしながら, 今回は その化合物の特定までにはいたらなかった。表面形態の定量 化之金属光沢が得られない条件における表面化合物の特定は 今後の課題である。

\section{4. 結言}

本研究では，金属光沢を具現化するための酸水溶液表面処 理条件の最適化を検討するとと屯に, 形成した膜の表面構造 を明らかにすることを目的とした。金属光沢の目標はエメ リー紙 \#2000 で研磨した AZ31 マグネシウム合金表面とした。 また, 化学研磨法の溶解反応機構で発生する水素が金属光沢 を阻害するという知見から ${ }^{23)}$ ，酸化剂添加と表面処理温度の 最適化による水素発生の抑制とその金属光沢に及ぼす効果に ついて検討した。これらの検討結果から，表面処理条件およ び表面構造と金属光沢の関係に関して考察した。その結果以 下のことが明らかとなった。

（1）超音波周波数 $28 \mathrm{kHz}$ 付加状態で $30 \mathrm{~s}$ 間浸漬する表面 処理条件において, 最適な表面処理液は $0.3 \sim 0.5 \mathrm{~mol} \mathrm{dm}^{-3}$ 硝 酸に $0.01 \mathrm{~mol} \mathrm{dm}^{-3}$ 有機酸を添加した水溶液であり, 最適な温 度は $278 \mathrm{~K}$ である。

（2）最適条件の酸水溶液処理によって得られた表面皮膜 は, 皮膜中のマグネシウムの約 $60 \%$ 以上が酸化された安定 な膜構造であり，かつその皮膜膜厚が $55 \mathrm{~nm}$ 程度であった。

（3）酸化剂添加を含む表面処理液成分および表面処理温度 の最適化が水素発生の抑制に効果的であり，それにより優れ た金属光沢を具現化することを確認した。

（4）金属光沢が得られる条件の場合, 表面近傍での酸化マ グネシウムの形成反応速度は酸化マグネシウムで構成されて いる表面皮膜からのマグネシウムの溶解速度よりも速いと推 測した。

（5）金属光沢が得られない条件の場合，水素発生に起因し て表面が荒れると推測した。

\section{謝辞}

最後に, 本実験の GD-OES 測定にご協力を頂いた株式会社 堀場製作所に感謝いたします。また，X線回折測定について は SPring-8 の先端大型研究施設戦略活用プログラムの公募採 択課題（2005B0932）として実施しました。ご協力をいただ いた財団法人高輝度光科学研究センターに感謝いたします。

\section{参 考 文 献}

1）小島 陽，鎌土重晴：工業材料， 50-8（2002），18-24.

2) H. Okahara, M. Ohara, Y. Takigawa and K. Higashi: Mater. Trans., 47 (2006), 954-958.

3) T. Kumagai, K. Shimamura, H. Okahara, Y. Takigawa and K. Higashi: Mater. Trans., 47 (2006), 1008-1012.

4) E. Goto, T. Kachi, H. Okahara, Y. Takigawa and K. Higashi: Mater. Trans., 47 (2006), 1782-1787.

5）笹谷純子, 岡原治男, 矢野正之, 白川信彦, 東 健司 : 素形材, 47-5 (2006), 30-34.

6）高谷松文：軽金属，50（2000），567-576.

7) K. A. Rayburn and T. W. Rodgers: Metal Finishing, 86-11 (1988), 15-17.

8）梅原博行，高谷松文，小島 陽：表面技術，50（2000，１09115 . 
9）森田良治, 金子秀昭, 木下賢一郎：軽金属，50（2000），560566.

10）小野幸子：表面技術，53（2002），166-171.

11）小野幸子, 木島秀夫，増子 昇：表面技術，53（2002），406412.

12) M. Hara, K. Matsuda, W. Yamauchi, M. Sakaguchi, T. Yoshikata, Y. Takigawa and K. Higashi: Mater. Trans., 47 (2006), 1013-1019.

13) M. Hara, K. Matsuda, W. Yamauchi, M. Sakaguchi, T. Yoshikata, Y. Takigawa and K. Higashi: Mater. Trans., 48 (2007), 3118-3125.

14) N. Hara, Y. Kobayashi, D. Kagaya and N. Akao: Corrosion Science, 49 (2007), 166-175.

15）関口将士，大谷 親，高谷松文：軽金属，56（2006）, 156-161.

16）日野 実, 村上浩二, 村岡 賢, 西條充司, 金谷輝人：軽金属, 57 (2007), 583-588.

17）日野 実，村上浩二，西條充司，金谷輝人：表面技術， 58 (2007), 767-773.

18）阿相英孝, 酒井郁洋, 生出章彦, 小野幸子：軽金属, 54 (2004), 567-572.

19）小野幸子, 木島秀夫, 増子 昇 : 軽金属, 52（2002）, 115121.

20）小野幸子, 三宅めぐみ，阿相英孝：軽金属，54（2004），544550.

21) K. Murakami, M. Hino, M. Hiramatsu, K. Nakai, S. Kobayashi, A. Saijo and T. Kanadani: Mater. Trans., 48 (2007), 3101-3108.

22）『高級感』を演出するための質感・素材感表現と色・光沢の使 い方，技術情報協会，（2007）。

23）佐治 孝：金属表面技術，14（1963），129-134.

24) W. J. Mcg. Tegart: The Electrolytic and Chemical Polishing of Metals in Research and Industry, Pergamon Press, (1956).
25）間宮富士雄, 山口 裕, 渡辺與七 : 化学研磨と電解研磨, 槙書 店, (1997)。

26）石澤克修，野村 健，村重信之：真空， 50（2007），47-52.

27）川村利光：表面技術，57（2006），768-772.

28）栗巣普揮, 木本 剛, 藤井寛朗, 田中和彦, 山本節夫, 松浦 満, 石澤克修, 野村 健, 村重信之 : 真空, 49（2006）, 254258.

29) P. Kneisel: Proceeding of SRF Workshop 1980, Karlsruhe, Germany, SRF80-2, (1980), 27-40.

30）西浜幸男：表面技術，48（1997），304-309.

31）新藤恵美, 吉田 明, 松本誠臣 : 表面処理, 51（2000）, 633639 .

32）田島 栄: 電解研磨と化学研磨, 産業図書, (1952).

33）森島 毅, 二見一男, 村上匡史, 和気 純：日本印刷学会誌, 32 (1995), 356-360.

34）白石徳明, 樋口浩一: 広島県立総合技術研究所西部工業技術セ ンター研究報告，50 (2007)，61-65.

35）岡原治男：アルトピア，2003-2（2003）, 21-26.

36）小原美良, 岡原治男, 東 健司：表面技術，56（2005）, 698-699.

37) M. Ohara, H. Okahara, Y. Takigawa and K. Higashi: Mater. Trans., 49 (2008), 909-912.

38) M. Ohara, Y. Takigawa and K. Higashi: Materials Science Forum, 610-613 (2009), 999-1002.

39) M. Ohara, Y. Takigawa and K. Higashi: Proc. of 138th TMS Annual Meeting \& Exhibition, Magnesium Technology 2009 (2009), 343-345.

40） JIS Z 8741 ：日本規格協会，（1997）。

41）柿田和俊：表面技術，52（2001），674-678.

42）春山志郎：表面技術者のための電気化学, 丸善, (2001), 189. 